\title{
Stabilization of Coal Mine Waste and Its Practical Application as a Road Subgrade
}

\author{
Mosammat Shamima Shirin, Mohammad Mohayminul Islam*, Mohammad Kumruzzaman \\ Department of Civil Engineering, Rajshahi University of Engineering and Technology, Rajshahi, Bangladesh \\ Email address: \\ shamima091@yahoo.com (M. S. Shirin), mohayminul.islam37@gmail.com (M. M. Islam), kzzaman2000@gmail.com (M. Kumruzzaman) \\ ${ }^{*}$ Corresponding author
}

\section{To cite this article:}

Mosammat Shamima Shirin, Mohammad Mohayminul Islam, Mohammad Kumruzzaman. Stabilization of Coal Mine Waste and Its Practical Application as a Road Subgrade. American Journal of Traffic and Transportation Engineering. Vol. 5, No. 5, 2020, pp. 51-56. doi: $10.11648 /$ j.ajtte. 20200505.11

Received: October 3, 2020; Accepted: October 19, 2020; Published: October 30, 2020

\begin{abstract}
A developing country like Bangladesh is establishing many power plants where coal is being used as a primary fuel. The generation of coal waste is increasing with the mining of coal, which may cause an adverse environmental effect. So, it is required to be managed in a proper manner, such as reuse and recycle the coal waste. The objective of this study is to investigate the significance of coal waste used as a road subgrade. Due to the lack of some physical and strength properties, the waste cannot be used directly as a subgrade. So, the investigation was done to stabilize the fresh coal waste with different percentages of fly ash such as $0 \%, 10 \%, 12 \%$ and $15 \%$ to justify the suitability of its intended use. It is found that with the increasing percentages of fly ashes, the plasticity index reduces significantly. With the addition of fly ash, the dry density increases, while the optimum moisture content decreases significantly. After analyzing the test result, it is found that coal waste with $15 \%$ fly ash having unconfined compressive strength and CBR value is 17.79 psi and $23.12 \%$ respectively which is sufficiently significant for use as road subgrade.
\end{abstract}

Keywords: Coal Mine Waste, Fly Ash, Road Subgrade, Waste Treatment

\section{Introduction}

Electricity is the key for development of any country. Coal is a major source of fuel for production of electricity in many countries round the globe [1]. The rapid economic development and industrialization has created a vast demand of energy all over the world [2]. The reason we keep building coal-based power plants is because it's so inexpensive to use coal as an energy source. In addition, the experts have announced that the amount of gas reserve in Bangladesh will be diminished by 10-15 years. To sort out this upcoming problem initially, the government of Bangladesh is concentrating on construction of coal fired power plants.

Bangladesh has a three billion tons reserve of bituminous coal inside our five discovered coal mines- Barapukuria, Phulbari, Dighipara, Jamalganj, and Khalashpir. Coal from these coal mines are of low ash, low Sulphur, and high caloric value [3]. The coal-based power plants burn a vast amount of coal in a year and excessive amount of mining waste discharged in the process of coal production and large quantity of fly ash get produced and becomes available as a byproduct of coal-based power stations [4]. The only coal-based power plant established by Bangladesh yet is Barapukuria thermal power plant (BTPP) which is situated near the Barapukuria Coal Mine Co. Ltd. to ease the supply of coal to the power plant. This $525 \mathrm{MW}$ power plant is consisting of two $125 \mathrm{MW}$ units and one $275 \mathrm{MW}$ [8]. Three other coal-based power plant, Matarbari Power Station (1200 MW), Payra Thermal Power Plant (1320 MW), and Rampal Power Plant (1320 MW) is under construction.

In 2015-16 financial year, the Barapukuria coal mine, Bangladesh produced 1,021,638 metric tons coal and in 2016-2017 financial year it was $1,160,657$ metric tons which is 139,019 metric tons more than the production of previous year. As production is being increased, the amount of waste generated from coal mining and processing operation is also increasing alarmingly. To minimize the environmental impact of mining it requires a well-planned control measure. Most of this waste is disposed on the surface which is inappropriate [5]. 
Now, it is high time to study the impact of power plant waste and coal mining waste on surrounding environment of Barapukuria and inhabitants [4]. In the field of civil engineering, use of this waste as filling materials for road subgrade work may be a potential way to minimize the detrimental effects of waste disposal [18, 19]. Subgrade soils are an essential component of pavement structures, and inadequate subgrade performance is the cause of many premature pavement failures. Lime and cement have been used successfully for many decades, and more recently fly ash has been used as an economical alternative to improve subgrade performance [16]. To evaluate the possibility of the coal waste material as a road subgrade, various engineering and mechanical properties of waste are to be investigated so as to ensure desired strength and durability [5].

This study aimed at the i) Suitability of the coal waste as a subgrade material instead of conventional materials. ii) Stabilization and strengthening of the coal waste using fly ash at different proportion iii) Determination of the optimum composition on coal waste and fly ash.

\section{Methodology and Materials}

\subsection{General}

To conduct the research work coal waste and fly ash were used. Coal waste was collected from Barapukuria coal mine (Bangladesh) and fly ash was collected from Barapukuria Thermal Power Plant (BTPP). After collecting the sample, physical properties of the coal waste were determined. Then the coal waste was stabilized with different percentages of fly ashes, compressive strength of the mixes was determined and finally their strength was compared. California Bearing Ratio (CBR) was also conducted to check the adequacy of coal waste as a subgrade material. The coal mine waste samples to be tested were designated as Type I, Type II, Type III and Type IV as presented in Table 1.

Table 1. Sample designation for different percentages of fly ashes.

\begin{tabular}{ll}
\hline Mix Proportion & Sample Designation \\
\hline Fresh Coal Mine Waste & Type I \\
Fresh Coal Mine Waste $+10 \%$ Fly Ash & Type II \\
Fresh Coal Mine Waste $+12 \%$ Fly Ash & Type III \\
Fresh Coal Mine Waste $+15 \%$ Fly Ash & Type IV \\
\hline
\end{tabular}

\subsection{Coal Waste}

In this research work dry coal waste was collected from the different sites of Barapukuria Coal Mine (Bangladesh). The index and physical properties of the fresh coal waste is shown in Table 2.

Table 2. Index properties of fresh coal waste.

\begin{tabular}{lll}
\hline & Values \\
\hline & Liquid Limit, $W_{L}(\%)$ & 33.89 \\
Property & Plastic Limit, $W_{P}(\%)$ & 12.15 \\
Name & Plasticity Index, $I_{P}(\%)$ & 21.74 \\
& Specific Gravity, $G_{s}$ & 2.57 \\
& Moisture Content, $w(\%)$ & 46.33 \\
\hline
\end{tabular}

\begin{tabular}{lll}
\hline & & Values \\
\hline & $C_{u}$ & 13.33 \\
& $\mathrm{C}_{c}$ & 0.37 \\
\multirow{2}{*}{ Soil } & USCS & CL (Inorganic Fine-grained \\
Classification & AASHTO & soil with Silts and Clays) \\
& ASH (14) \\
\hline
\end{tabular}

\subsection{Fly Ashes}

$27 \%$ of electricity demand round the world is met up by coal generated electric power [1]. Burning of coal produces a hollow, vitrified, and spherical shaped waste materials as a byproduct in the chimney of the plant that burning the coal is termed fly ash [8]. It is found in the form of very fine powder which is mainly composed of silica which is produced due to the burning of finely crushed coal in the boiler to generate power. Its main constituents are silica $\left(\mathrm{SiO}_{2}\right)$, alumina $\left(\mathrm{Al}_{2} \mathrm{O}_{3}\right)$, ferric oxide $\left(\mathrm{Fe}_{2} \mathrm{O}_{3}\right)$, ferrous oxide $(\mathrm{FeO})$ and calcium oxide $(\mathrm{CaO})$. It also contains small amount of $\mathrm{Na}_{2} \mathrm{O}, \mathrm{K}_{2} \mathrm{O}, \mathrm{MgO}$, $\mathrm{TiO}_{2}, \mathrm{SO}_{3}, \mathrm{MnO}, \mathrm{P}_{2} \mathrm{O}_{5}$ and unburned carbon [9]. For this research work, fly ashes were collected from Barapukuria thermal power plant (BTPP), Bangladesh. The chemical and physical properties of the fly ash sample collected are shown in Table 3. [8]

Table 3. Chemical composition of fly ash sample of BTPP determined by $X-R F$ analysis.

\begin{tabular}{lll}
\hline & Composition/ Physical Properties & Values (\%) \\
\hline & $\mathrm{SiO}_{2}$ & 50.2 \\
& $\mathrm{Al}_{2} \mathrm{O}_{3}$ & 40.1 \\
& $\mathrm{Fe}_{2} \mathrm{O}_{3}$ & 3.32 \\
Chemical & $\mathrm{CaO}$ & 1.92 \\
Composition & $\mathrm{MgO}$ & 0.20 \\
& $\mathrm{SO}_{3}$ & 0.45 \\
& $\mathrm{ZnO}$ & 0.0078 \\
& $\mathrm{PbO}$ & 0.0068 \\
& Liquid Limit, $W_{L}(\%)$ & 47 \\
& $\mathrm{Plastic}$ Limit, $W_{P}(\%)$ & 0 \\
Physical & Specific Gravity, $G_{s}$ & 2.12 \\
& Moisture Content, $w(\%)$ & 1.08 \\
& Loss on ignition $(\%)$ & 2 \\
\hline
\end{tabular}

\subsection{Experimental Methods and Standards}

The specific gravity test was carried out using ASTM D 854-00. Grain size analysis (sieve analysis and hydrometer analysis) of fresh coal waste was executed according to ASTM D 421 and D 422. Modified proctor test was performed to determine the optimum moisture content and maximum dry density for all the mixtures according to ASTM D 1557. The Atterberg's limits were assessed according to ASTM D 4318. ASTM D 2166 Standard test method for unconfined compressive strength was adopted for the determination of unconfined compression strength for each of the mixtures. California Bearing Ratio test (CBR) both unsoaked and soaked condition was performed for all the mixtures according to ASTM D 1883. 


\section{Result and Discussion}

\subsection{Grain Size Distribution}

Both sieve analysis and hydrometer analysis were performed for fresh coal mine waste and the result is illustrated in a grain size distribution curve in [Figure 1]. The grain size distribution curve depicts that the sample is well graded. Effective size $\left(\mathrm{D}_{10}\right)$ is 0.0047 , Coefficient of gradation $\left(\mathrm{C}_{\mathrm{c}}\right)$ is 0.37 , Uniformity coefficient $\left(\mathrm{C}_{\mathrm{u}}\right)$ is 13.33 , and Sorting coefficient $\left(\mathrm{S}_{\mathrm{o}}\right)$ is 2.95. As much the $\mathrm{D}_{10}, \mathrm{C}_{\mathrm{c}}$ and $\mathrm{C}_{\mathrm{u}}$ increases the CBR value increases [17]. The particle size is good to be used as a subgrade material.

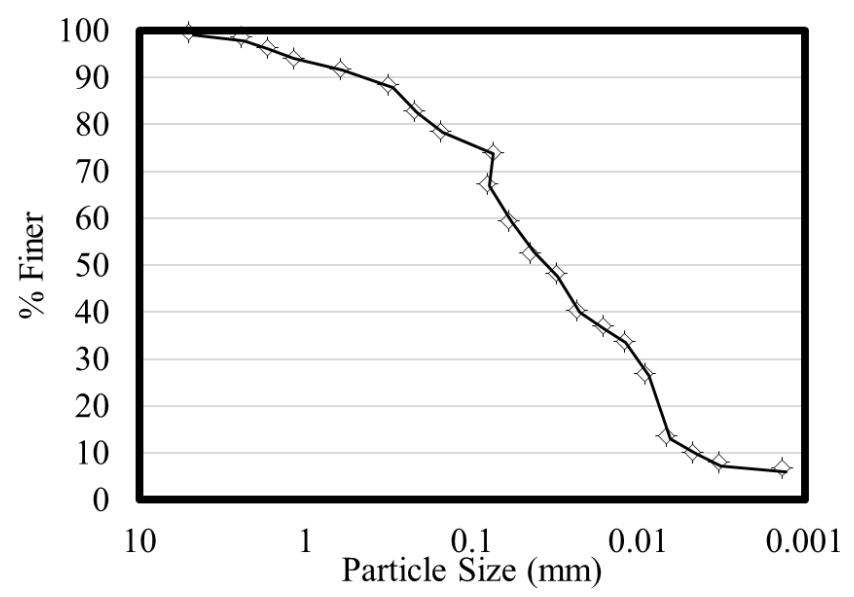

Figure 1. Particle size distribution curve of fresh coal mine waste.

\subsection{Index Properties}

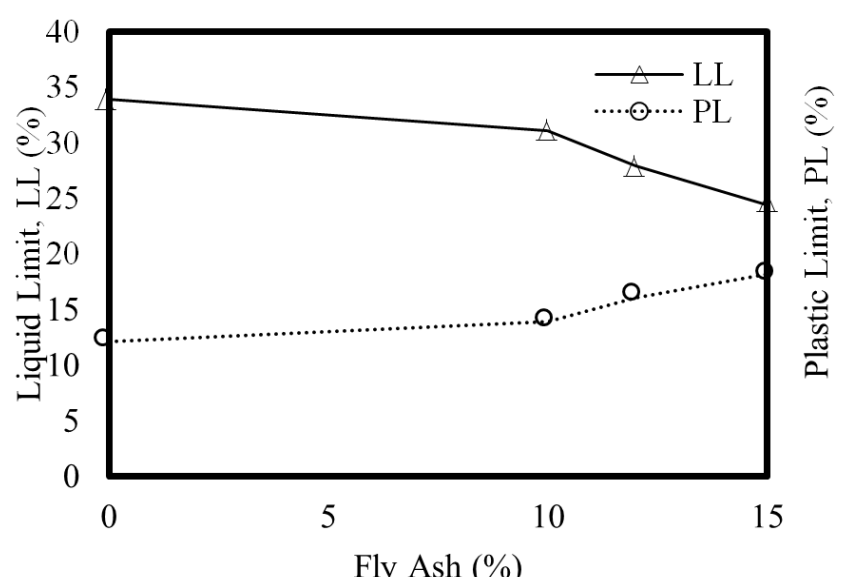

Figure 2. Variation of liquid limit and plastic limit with varying percentages offly ashes.

Atterberg's limit is crucial for the characterization of soil in elaborated category. [Figure 2] shows the variation of liquid limit and plastic limit with increasing percentage of fly ash. It is observed that liquid limit is decreases with the increasing percentages of fly ashes. But the plastic limit increases with the addition of fly ash. These trends are the same as those produced when soils are treated with lime, rice husk ash, and cement [1215]. They said that these beneficial changes in engineering properties are mainly attributed to cation exchange, flocculation of the clay, agglomeration, and pozzolanic reactions. The liquid limit ranges $33.89 \%$ to $24.37 \%$ and the plastic ranges from $12.15 \%$ to $18.18 \%$. The plasticity index is also decreasing with the addition of fly ash gradually [Figure 3]. Due to the hydration process, liquid limit and plasticity index are decreased gradually. Moreover, fly ash chemically reacts with the particles of coal mine wastes which effectively changes the soil grain clay size to silt size. If plasticity index is less than $10 \%$, then it can be used as road subgrade [5]. From the [Figure 2] it is found that the plasticity index for $15 \%$ of fly ash is 7 and for the other proportion on fly ash it is more than 10 . So, addition of $15 \%$ of fly ash which is designated as Type IV can be used as road sub grade.

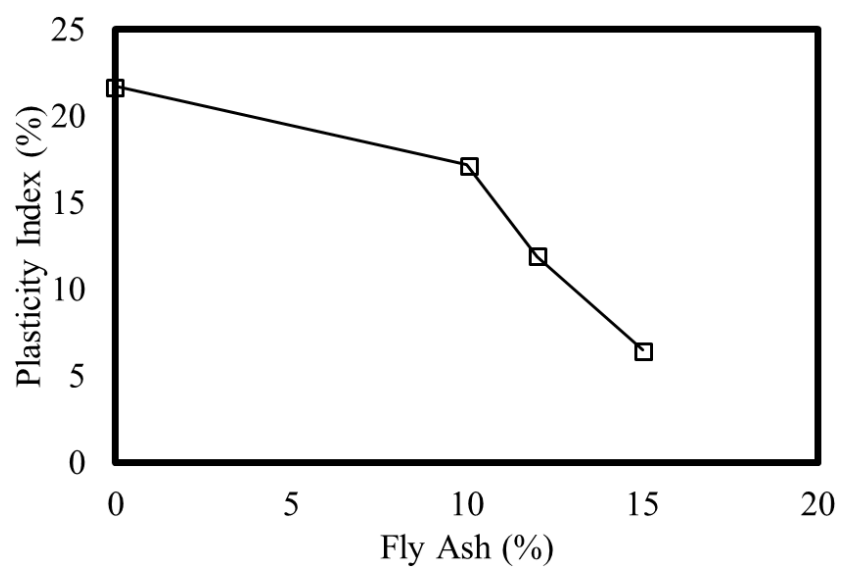

Figure 3. Variation of plasticity index with varying percentages of fly ashes.

\subsection{Compaction Characteristics}

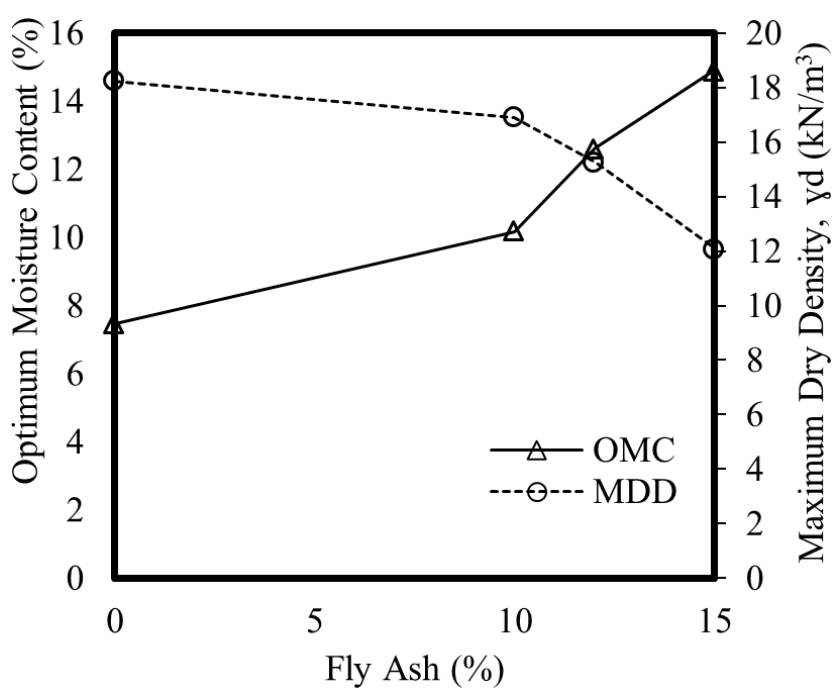

Figure 4. Variation of $O M C$ and $M D D$ with varying percentages of fly ashes.

"Figure 4" illustrates the effects of fly ash on OMC and MDD. It is seen that the OMC decreases with the increasing percentages of fly ashes but it is observed opposite for MDD. The void ratio of soils depends upon the shape of the grains, the uniformity of grain size, and the conditions of sedimentation. The addition of fly ash in soils changes the porosity and void ratio within the range of void ratio of fly ash and soils. At maximum, the void ratio and porosity are 
free from moisture [11]. The optimum moisture content increases from $7.47 \%$ to $14.90 \%$ and the maximum dry density decreases from $18.22 \mathrm{kN} / \mathrm{m}^{3}$ to $12.10 \mathrm{kN} / \mathrm{m}^{3}$ from Type I to Type IV. The same output is observed during the use of cement with sand [5]. Also Kaniraj and Havanagi [10] described that the decrease in the maximum dry density is imputed to the agglomeration and flocculation of clay particles through cation exchange reaction and also leading to the occupation of a larger space.

\subsection{Unconfined Compression Strength (UCS)}

For observing the usefulness of fly ash in improving the coal waste properties unconfined compressive strength test were conducted. The changes in unconfined compressive strength for different types of mixes are shown in the following [Figure 4]. The fresh coal waste has a lower compressive strength. But after the addition of fly ash the strength increases rapidly. The reason for this improvement is the formation of cementing gels (hydrate) due to the reactions between $\mathrm{CaO}$ of ash with $\mathrm{Al}_{2} \mathrm{O}_{3}$ and $\mathrm{SiO}_{2}$ of soil. This results in the agglomeration of large size particles and causes the increase in compressive strength [9]. The unconfined compressive strength increased from $17.54 \mathrm{kPa}$ (Type I) to $122.75 \mathrm{kPa}$ (Type IV) in this study. When the UCS value less than $25 \mathrm{kPa}$ then the quality of subgrade is very low. When the UCS value lies between $50 \mathrm{kPa}$ to 100 kpa then the subgrade is medium and when the UCS value lies 100 to $200 \mathrm{kPa}$ then the subgrade is stiff [5]. The result indicates that fresh coal mine is very soft. Therefore, it is not suitable to be used as road subgrade. The UCS value for Type IV for is $122.75 \mathrm{kPa}$, so it can be used as road subgrade.

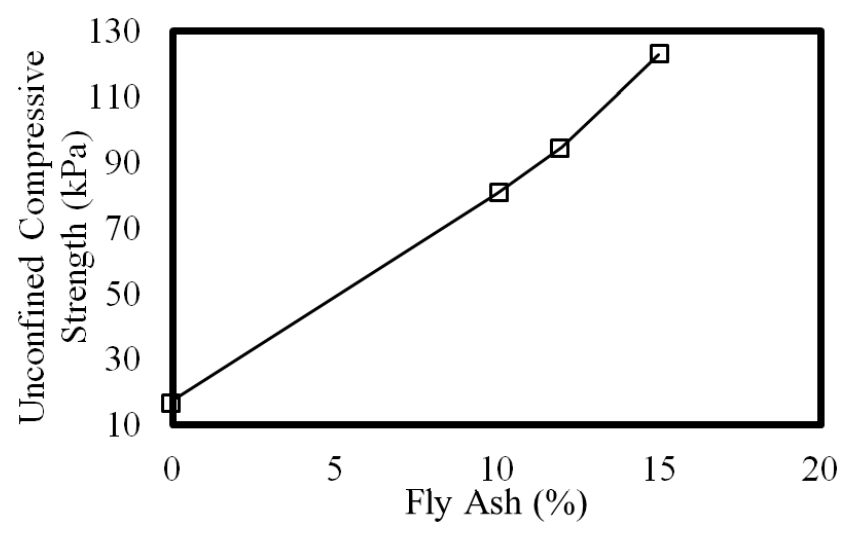

Figure 5. Variation of UCS with varying percentages of fly ashes.

\subsection{California Bearing Ration (CBR)}

The results of CBR test for both unsoaked and soaked condition are shown in "Figure 6" \& "Figure 7". It shows that the addition of fly ash has greatly influenced the CBR value. The similar trend is found from Prabakar J. [11]. It is observed from the figure that in case of Type I the unsoaked sample has a larger CBR value than soaked sample. But the CBR value is reversed after addition of fly ash for Type II, Type III and Type IV. This is happened due to the binding property of fly ash which has added with coal mine waste along with water. As a result, the sample mass has hardened considerably than that of unsoaked condition and hence it possessed comparatively more strength preventing the penetration in CBR test. Un-soaked CBR value increases from $1.08 \%$ (Type I) to $28.16 \%$ (Type IV) and soaked CBR value increases from $0.58 \%$ (Type I) to $42.87 \%$ (Type IV). This indicates the improvement in strength of the mixes after adding fly ash gradually. The expansion ratio decreases from 1.51 to (Type I) to 0.26 (Type IV) with the addition of fly ash. These values indicate that the improved coal waste sample have more acceptable values than fresh coal waste sample. The soil to be used as subgrade should have an expansion ratio less than 1 [5]. After improvement every mix has shown an expansion ratio below 1 and hence any of the improved samples is suitable as road subgrade. Besides, the CBR value in between $3 \%$ to $5 \%$ denotes a subgrade material with normal strength and that in between $5 \%$ to $15 \%$ indicates a subgrade with good strength [5]. Therefore, any of the three improved coal mine waste mixes can be considered as a subgrade with good strength and can be accepted as road subgrade material.



Figure 6. Variation of $C B R$ with varying percentages of fly ashes for Unsoaked Condition.

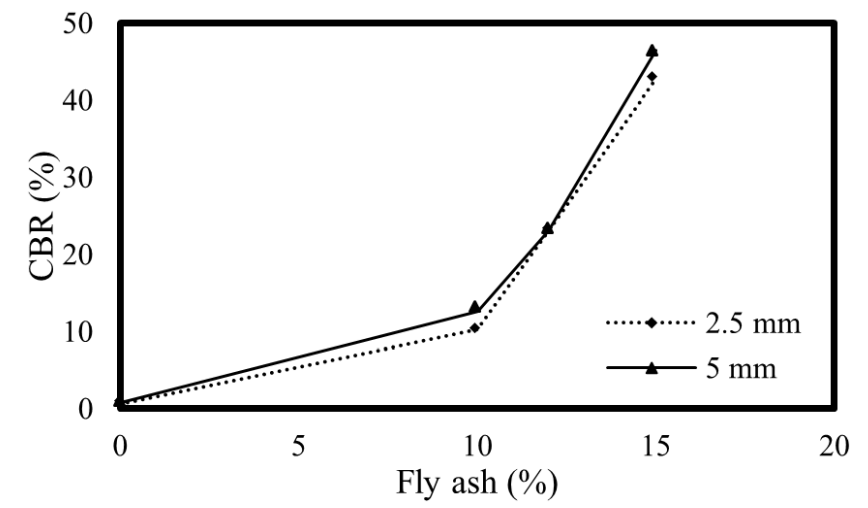

Figure 7. Variation of CBR with varying percentages of fly ashes for soaked Condition.

\section{Conclusion}

The objective of this study was to determine the suitability of coal mine waste as a road subgrade. Improvement of the strength of soil by using binding material is very common in 
Bangladesh. Tests were conducted by stabilizing the coal waste with fly ash at four different percentages $(0 \%, 10 \%, 12 \%$ and $15 \%)$. The following conclusions are drawn from the study.

Incorporation of fly ash into the waste material reduces the moisture content and increases the dry density gradually.

From the Atterberg test result it is observed that the liquid limit decreases and the plastic limit increases and hence the plasticity index decreases with the increasing percentages of fly ash content.

Incorporation of fly ash into the waste material significantly increase the compressive strength very quickly. This advantage is particularly important because the larger loads to be superimposed on the subgrade frequently occur during construction of the road and improvement of the associated properties.

Increase in the CBR value for both soaked and un-soaked condition due to the addition of fly ash are substantial. Un-soaked CBR value increases from $1.08 \%$ to $28.16 \%$ and soaked CBR value increases from $0.58 \%$ to $42.87 \%$.

Improved coal waste contributes to the strength of the road pavement system and it may protect the surrounding environment of Barapukuria, Bangladesh and its inhabitants from detrimental effect.

Finally, it can be concluded that the properties of coal waste can be improved by adding fly ash and the improved waste material can be used as a road subgrade. Further study is required to analyse the water that will infiltrate through the subgrade material will contaminate the ground water or not.

\section{Authors' Contributions}

All authors have same contributions to this Article.

\section{Acknowledgements}

First of all, we would like to recall the almighty Allah, whose kindness has helped us to end up with an extensive effort. We offer our sincere gratitude and thanks to Dr. Md. Kumruzzaman whose inspiring guidance and valuable suggestions have made this work possible. We would like to acknowledge that every author has equal contribution to this research work.

\section{References}

[1] Krishna Hygrieve M. S, Kishore Siva I. \& Chari KJB (2017), Comparative Study on Compressive Strength of Fly Ash Concrete, International Journal of Civil Engineering and Technology, Volume 8, Issue 4., Page 1737-1738.

[2] Kibria M. G., Quamruzzaman, C., Ullah, A. S. M. W. \& Kabir, A. K. M. F. (2012). Effect of longwall mining on groundwater forunderground coal extraction in Barapukuria, Bangladesh. Journal of mines, metals \& fuels, Volume 2, Page 60-66.

[3] Hossain Nazir Md., Paul Kumar Shitangsu \& Hasan Muyeed Md. (2015), Environmental impacts of coal mine and thermal power plant to the surroundings of Barapukuria, Dinajpur, Bangladesh, Springer International Publishing, Volume 3, Page 1-3.
[4] Yanli Huang, Jixiong Zhang, Qiang Zhang; \& Shoujiang Nie (2011), Backfilling Technology of Substituting Waste and Fly Ash for Coal Underground in China Coal Mining Area, Environmental Engineering and management Journal, Volume 10, No. 6, June 2011, Page 769.

[5] Hossain M. B., Kumruzzaman M. and Roknuzzaman M. (2018), Study of Engineering Behavior of Coal Mine Waste Generated from Barapukuria Coal Mine as Road Subgrade, Journal of Civil Engineering Science and Technology, Volume 9, Issue 1, Page 58.

[6] Gorakhki, Mohammad H., Sultan A. Alhomair, \& Christopher A. Bareither. (2017). Re-Use of Mine Waste Materials Amended with Fly Ash in Transportation Earthworks Projects. Research Report - MPC Publications: MPC-17-332. North Dakota State University - Upper Great Plains Transportation Institute, Fargo: Mountain-Plains Consortium.

[7] Hilmi Lab A., Lay Aysen M. \& Goktepe Burak A. (2005), Analysis and Design of a Stabilized Fly Ash as Pavement Base Material, World of Coal Ash (WOCA), Lexington, Kentucky, USA. Page 2-3.

[8] Md. Anwar Arfien Khan, Madhu Sudan Saha, Sharmin Sultana, Aninda Nafis Ahmed and Rajib Chandra Das (2013), Coal Fly Ash of Barapukuria Thermal Power Plant, Bangladesh: Physico Chemical Properties Assessment and Utilization, International Journal of Scientific \& Engineering Research, Volume 4, Issue 11, Page 1456-1460.

[9] Bayshakhi Deb Nath, Md. Keramat Ali Molla, and Grytan Sarkar, Study on Strength Behavior of Organic Soil Stabilized with Fly Ash, International Scholarly Research Notices, Volume 2017, Article ID 5786541, 6 pages.

[10] Kaniraj, S. R. and Havanagi, V. G. "Behavior of cement-stabilized fiber-reinforced fly ash-soil mixtures," Journal of Geotechnical and Geoenvironmental Engineering, vol. 127, no. 7, pp. 574-584, 2001.

[11] J. Prabakar, N. Dendorkar, and R. K. Morchhale (2004.) "Influence of fly ash on strength behavior of typical soils," Construction and Building Materials, vol. 18, no. 4, pp. 263267.

[12] T. H. T. Ogunribido, "Geotechnical properties of saw dust ash stabilized southwestern Nigeria lateritic soils," Environmental Research, Engineering and Management, vol. 2, no. 2, pp. 2933, 2012.

[13] G. Sarkar, M. R. Islam, M. Alamgir, and M. Rokonuzzaman,"Study on the geotechnical properties of cement based composite fine-grained soil," International Journal of Advanced Structures and Geotechnical Engineering, vol. 1, no. 2, pp. 2319-5347, 2012.

[14] G. Sarkar, R. Islam, M. Alamgir, and M. Rokonuzzaman, "Interpretation of rice husk ash on geotechnical properties of cohesive soil," Global Journal of Research in Engineering, vol. 12, no. 2, pp. 1-7, 2012.

[15] K. J. Osinubi and A. O. Eberemu, "Effect of bagasse ash on the strength of stabilized lateritic soil," in Proceedings of the $5^{\text {th }}$ Nigerian Material Congress, pp. 214-220, Abuja, Nigeria, November 2006.

[16] R. L. Parsons and E. Kneebone, "Field performance of fly ash stabilised subgrades," Ground Improvement, vol. 9, no. 1, pp. 33-38, 2005. 
[17] Duque, J.; Fuentes, W.; Rey S., Enois M., "Effect of Grain Size Distribution on California Bearing Ratio (CBR) and Modified Proctor Parameters for Granular Materials" Arabian Journal for Science and Engineering, 2020.

[18] Harun-or-Rashid, G. M., Islam, M. M. (2020), A Review Paper on: Effect of Different Types of Filler Materials on Marshall Characteristics of Bitumen Hot Mix. 9: 40-46. https://doi.org/10.11648/j.ijmsa.20200903.11.
[19] Islam, M. M., Islam, M. S., Rahman, F. I., (2019) A Brief Study on Capacity Loss at Major Rajshahi City Roads, Bangladesh. In: Proceedings of International Conference on Planning, Architecture and Civil Engineering. Rajshahi, Bangladesh, pp $1-6$. 